\title{
FAKTOR YANG BERHUBUNGAN DENGAN PEMANFAATAN PELAYANAN ALAT KONTRASEPSI KB PADA PASANGAN USIA SUBUR DI PUSKESMAS TAMALANREA KOTA MAKASSAR 2019
}

\author{
*)Asridawati Akib \\ *)Akademi Kebidanan Sandi Karsa Makassar \\ *)Program Studi D-III Kebidanan Sandi Karsa Makassar
}

\begin{abstract}
ABSTRAK
Telah dilakukan penelitian mengenai Faktor yang Berhubungan dengan Pemanfaatan Pelayanan Alat Kontrasepsi KB pada Pasangan Usia Subur di Puskesmas Tamalanrea Kota Makassar. Penelitian ini bertujuan untuk mengetahui hubungan antara umur, pengetahuan, pendidikan, pekerjaan, pemberian informasi, dan dukungan suami dengan pemanfaatan pelayanan alat kontrasepsi KB pada Pasangan Usia Subur. Metode penelitian ini adalah penelitian kuantitatif dengan pendekatan secara cross sectional study. Penelitian ini dilaksankan di Puskesmas Tamalanrea. Populasi 3332 dengan sampel 97 responden yang merupakan pasangan usia subur. Pengumpulan data dilakukan dengan cara membagikan kuesioner kepada responden dengan pengolahan data SPSS. Penyajian data dalam bentuk tabel distribusi frekuensi. Hasil penelitian ini menunjukkan bahwa ada berhubungan dengan pemanfaatan pelayanan alat kontrasepsi KB pada pasangan usia subur di Puskesmas Tamalanrea Makassar yaitu umur $(\mathrm{p}=0,009)$, pendidikan $(\mathrm{p}=0,046)$, pemberian informasi $(\mathrm{p}=0,036)$, dan dukungan suami $(\mathrm{p}=0,038)$. Sedangkan yang tidak memiliki hubungan antara pemanfaatan pelayanan alat kontrasepsi KB pada pasangan usia subur di Puskesmas Tamalanrea Makassar yaitu pekerjaan $(p=0,291)$ dan pengetahuan ( $\mathrm{p}=0,448)$. Kesimpulan dari penelitian adalah faktor yang berhubungan dengan pemanfaatan pelayanan alat kontrasepsi KB pada pasangan usia subur di Puskesmas Tamalanrea yaitu ada hubungan antara umur, pendidikan, pemberian informasi, dukungan suami dan yang tidak memiliki hubungan antara pemanfaatan pelayanan alat kontrasepsi KB pada pasangan usai subur yaitu pengetahuan dan pekerjaan. Disarankan bagi petugas kesehatan memberikan informasi tentang pemanfaatan pelayanan alat kontrasepsi KB pada pasangan usia subur untuk meningkatkan pengetahuan tentang penggunaan alat kontrasepsi.
\end{abstract}

Kata kunci: KB, Alat Kontrasepsi, Usia Subur.

\section{PENDAHULUAN}

\section{A. Latar Belakang}

Salah satu masalah kependudukan utama di Indonesia adalah pertumbuhan penduduk yang tinggi, hingga saat ini telah dilakukan berbagai usaha untuk mengendalikan pertumbuhan angka kelahiran. Berbagai program pembangunan telahdilaksanakan untuk mengatasi masalah kependudukan tersebut, antara lain melalui program pelayanan kesehatan ibu dan anak, keluarga berencana dan pembangunan keluarga sejahtera. Upaya penurunan angka kelahiran dilakukan dengan cara pemakaian kontrasepsi secara sukarela kepada pasangan usia subur. (BKKBN, 2009).

Tingginya pertumbuhan penduduk di Indonesia merupakan masalah utama yang dihadapi Indonesia. Dinamika laju pertumbuhan penduduk di Indonesia saat ini cukup tinggi. Berdasarkan sensus 2010 diketahui bahwa pertumbuhan penduduk melebihi proyeksi nasional yaitu sebesar 237,6 juta jiwa dengan laju pertumbuhan penduduk (LPP) 1,49 per tahun sedangkan pada tahun 2013 diperkirakan penduduk Indonesia mencapai 250 juta dengan pertumbuhan penduduk $1,49 \%$ bahkan hingga 1,5 persen per tahun. Hal ini tidak menunjukan penuruna justru malah sebaliknya sehingga sudah mengkhawatirkan. Jika laju pertumbuhan tidak ditekan maka jumlah penduduk di tanah air pada 2045 menjadi 450 juta jiwa . Ini berarti satu dari 20 penduduk dunia adalah orang Indonesia (BKKBN, 2013).

Pemberian pelayanan alat kontrasepsi adalah upaya yang dilakukan untuk meningkatkan kualitas keluarga. Selama kurun waktu dua dasawarsa, pelayanan kontrasepsi dalam pembangunan KB di Indonesia telah memperoleh hasil yang cukup menggembirakan. Walaupun pada satu dasawarsa terakhir seakan-akan program KB terdengar lemah kegiatannya, namun ternyata dari data SDKI 2007 program KB ada keberhasilannya. Yakni ditandai dengan semakin meningkatnya prevalensi wanita usia subur yang menggunakan metode kontrasepsi. Pada SDKI tahun 2003 ada sebesar 57,4\% wanita menikah yang memakai alat kontrasepsi. Sedangkan pada SDKI 2007 didapatkan data sebesar $61,4 \%$ wanita menikah yang memakai alat kontrasepsi SDKI, 2008 (Fitri, 2015).

Keluarga berencana adalah usaha untuk menjarangkan atau merencanakan jumlah dan jarak kehamilan dengan memakai kontrasepsi. Tujuannnya adalah untuk meningkatkan kesehatan ibu dan anak serta mewujudkan norma keluarga kecil bahagian dan sejahtera yang menjadi dasar 
bagi terwujudnya masyarakat sejahtera dengan pengendalian kelahiran dan pertumbuhan penduduk. Hal tersebut diupayakan melalui gerakan reproduksi keluarga sejahtera, gerakan ketahan keluarga sejahtera dan gerakan ekonomi keluarga sejahtera dengan sasaran pasangan usia subur (BKKBN, 2010).

Pembangunan kesehatan diarahkan untuk meningkatkan sumber daya manusia serta kualitas dan usia harapan hidup manusia meningkatkan kesejahtraan keluarga dan masyarakat. Salah satu bentuk penyelanggaraan upaya kesehatan dilaksanakan melalui pemanfaatan pelayanan puskesmas, karena puskesmas merupakan pusat pembangunan kesehatan masyarakat dan pelayanan yang bermutu, merata dengan peran serta masyarakat yang aktif.

Menurut WHO, (1970), keluarga berencana adalah tindakan yang membantu pasangan suami istri untuk menghindari kehamilan yang tidak diinginkan, mendapatkan kelahiran yang memang tidak di inginkan, mengatur interval di antara kehamilan,mengontrol waktu saat kelahiran dalam hubungan dengan umur suami istri serta menentukan jumlah anak dalam keluarga (WHO, 1970).

Program keluarga berencana adalah untuk membangun manusia Indonesia sebagai objek dan subjek pembangunan melalui peningkatan kesejahteraan ibu, anak, dan keluarga. Selain itu program KB juga ditujukan untuk menurunkan angka kelahiran dengan menggunakan salah satu jenis kontrasepsi secara sukarela yang didasari keinginan dan tanggung jawab seluruh masyarakat. Upaya untuk menurunkan angka kelahiran sekaligus membentuk keluarga sejahtera merupakan cerminan dari program KB (Bappeda, 2013).

Salah satu kebijakn pemerintah untuk meningkatkan keluarga yang berkualitas, Pemerintah memanfaatkan BKKBN yang merupakan instansi yang secara khusus menangani masalah KB dengan merumuskan arah kebijakan dan strategi program KB menuju Visi "Keluarga Berkualitas" dimana keluarga berkualitas adalah keluarga sejahtera, sehat, maju, mandiri, jumlah anak yang ideal (Hartono, 2004).

Keluarga berencana merupakan salah satu cara yang efektif umtuk mencegah mortalitas ibu dan anak karena dapat menolong pasangan suami istri menghindari kehamilan resiko tinggi. Keluarga berencana tidak dapat menjamin kesehatan ibundan anak, tetapi dengan melindungi keluarga terhadap kehamilan resiko tinggi, $\mathrm{KB}$ dapat menyelamatkan jiwa dan mengurangi angka kesakitan (Hartono, 2004).

Menurut hasil SDKI menunjukkan bahwa pelayanan KB yang dilakukan oleh fasilitas pelayanan KB pemerintah baik di rumah sakit pemerintah maupun di puskesmas masih rendah yaitu hanya 22,2\% (SDKI 2007), angka ini lebih rendah dari survey sebelumnya yaitu 28\% (SDKI 2002/2003). Sedangkan pelayanan KB di rumah sakit pemerintah menurun dari $6,2 \%$ menjadi $4,9 \%$ dan pelayanan KB di puskesmas juga menurun dari 20,3\% (SDKI 2002-2003 menjadi hanya $16,0 \%$ (BKKBN 2013).

Hasil sensus penduduk tahun 2010 juga menunjukan Laju pertumbuhan (LPP) pertahun selama periode tahun 1971-1980 yakni sebesar $2,31 \%$ dan menurun secara tajam pada rentang tahun 1990-2000 yakni sebesar 1,40\%.Penerunan LPP ini di mungkinkan karena berhasilnya program keluarga berencana (KB) yang dicanangkan pemerintah saat itu.Sedangkan pada periode tahun 2000-2010 LPP sebesar 1,49\% per tahun terjadi sedikit peningkatan jika dibandingkan dengan LPP periode tahun 1990-2000 (Profil Kesehatan Indonesia 2010).

Secara nasional,menurut hasil pengumpulan data atau indikator kinerja standar pelayanan minimum (SPM) bidang kesehatan seluruh Indonesia menunjukan bahwa pada tahun 2003 persentase peserta keluarga berencana (KB) aktif sebesar $68,49 \%$. Sedangkan di Sulawesi Selatan pada tahun 2013, persentase peserta keluarga berencana (KB) aktif sebeser $67,48 \%$.

Berdasarkan data yang didapat dari badan pusat statistik provinsi Sulawesi selatan dengan laju pertumbuhan penduduk pada 2004-2008 rata-rata sebesar 1,32\%,sedangkan antara 2008-2009 melaju sebesar 6,69\% per-tahun.Dengan jumlah penduduk pada tahun 2010 sebesar 832.957 jiwa (Profil Kesehatan Sulawesi selatan, 2009).

Seiring dengan data yang didapat dari badan koordinasi keluarga berencana (BKKBN) provinsi sulawesi selatan tahun 2010 , untuk peserta keluarga berencana pada wilayah provinsi Sulawesi selatan adalah sebanyak 1.324.031 jiwa, sementara pasangan usia subur (PUS) sebanyak 1.644.784 jiwa.Untuk pemakaian alat kontrasepsi suntik sebanyak 410.834 akseptor $(31,03 \%)$, pil sebanyak 322.632 akseptor $(24,37 \%)$ implant sebanyak 85,631 akseptor (6,47\%), IUD sebanyak 41,450 akseptor $(3,13 \%)$ pemakaian kondom 15,040 akseptor (1,14\%), (BKKBN,Prov Sul-Sel, 2010).

Profil data kesehatan Indonesia tahun 2013 menunjukan tingkat kesertaan KB pada pasangan usia subur (PUS) di Indonesia telah mencapai $76,73 \%$ dengan perincian penggunaan kontrasepsi yaitu suntik $48,56 \%$, pil $26,60 \%$. Metode yang paling sedikit digunakan oleh peserta KB adalah metode oprasi pria (MOP) sebanyak $0,25 \%$, kemudian metode operasi wanita (MOW) sebanyak 1,25, dan kondom 6,09\%.Sedangkan pada tahun 2014 metode kontrasepsi yang paling banyak digunakan oleh peserta KB aktif adalah suntikan $(47,54 \%)$ dan terbanyak ke dua adalah pil $(23,58 \%)$. Sedangkan metode kontrasepsi yang paling sedikit dipilih oleh peserta KB aktif yaitu 
Metoda Operasi Pria (MOP) sebanyak 0,69\%, kemudian kondom sebanyak 3,15\% (Profil kesehatan Indonesia, 2014).

Untuk Provinsi Sulawesi selatan, persentae tertinggi alat/cara $\mathrm{KB}$ yang di pakai peserta $\mathrm{KB}$ aktif adalah suntikan (47,39\%), kemudian PIL $(22,90 \%)$, Kondom $(13,45 \%$,) dan lain-lainnya $(0,56 \%)$.Sedangkan persentase penggunaan kontrasepsi bagi peserta KB baru yang terbanyak suntikan (44,61\%), Pil (24,78\%), Kondom $(16,85 \%)$, Implant $(8,84 \%)$, IUD $(3,21 \%)$, MOW $1,04 \%)$, mop $(0,25 \%)$ dan lainnya $(0,28 \%)$, (BKKBN Provinsi Sul-Sel, 2013).

Khusus untuk wilayah kerja puskesmas tamalanrea memiliki cakupan peserta KB kontrasepsi yang meng alami peningkatan pada tahun 2011 sebesar 1507 akseptor $(25,8 \%)$ pada tahun 2012 sebesar 3011 akseptor $(51,5 \%)$ pada tahun 2013 sebesar 3332 akseptor (56,9\%), (Profil puskesmas tamalanrea 2013).

Faktor umur berperan dalam pemilihan kontrasepsi yang dingunakan sehingga kontrasepsi pada KB di sesuaikan dengan tahap masa reproduksi yang tidak terlepas dari keadaan dan fungsi-fungsi biologis tubuh wanita.Seorang ibu yang berumur di bawah 20 tahun dan di atas 35 tahun memiliki risiko morbiditas dan mortalitas pada saat persalinan. Pola perencanaan keluarga dengan mengatur jarak kehamilan dapat dilakukan untuk menghindari risiko (Suryani, 2006).

Faktor pengetahuan merupakan salah satu unsur yang diperlukan dalam perubahan pola pikir dan perilaku. Adanya pengetahuan tentang jenis alat kontrasepsi, keuntunganya dan kerugiannya akan mempengaruhi seseorang untuk memilih jenis kontrasepsi yang sesuai. Dengan pengetahuan yang cukup tentang KB dapat di pastikan wanita pasang usia subur akan mempunyai sikap yang positif terhadap kontrasepsi (Suryani, 2006).

Hasil penelitian Rifai (2013) bahwa yang dilakukan di puskesmas buhu di Kabupaten Gorontalo tentang penggunaan alat kontrasepsi KB pada pasangan usia subur disimpulkan bahwa ada hubungan antara pengetahuan dengan penggunaan alat kontrasepsi pada pasangan usia subur $(\mathrm{p}=0,000)$. Ada hubungan antara pendidikan dengan penggunaan alat kontrasepsi pada pasangan usia subur $(\mathrm{p}=0,000)$. Ada hubungan antara ketersedian alat kontrasepsi dengan penggunaaan alat kontrasepsi pada pasangan usia subur $(\mathrm{p}=0,000)$ dan tidak ada hubungan antara jumlah anak dengan penggunaaan alat kontrasepsi pada pasangan usia subur di wilayah kerja Puskesmas Buhu Kabupaten Gorontalo ( $\mathrm{p}=0,222 \leq$ nilai $\alpha=0,05)$.

Berdasarkan data atas diketahui di Puskesmas Tamalanrea metode kontrasepsi KB mengalami peningkatan bila dibandingkan dari tahun sebelumnya. Adanya peningkatan pada minat peserta KB yang paling banyak memilih metode kontrasepsi suntik daripada kontrasepsi lainnya dipengaruhi beberapa faktor yaitu; umur,tingkat pendidikan, status pekerjaan, jumlah anak, usia pertama kawin, pengetahuan, pemberian informasi, dan alat kontrasepsi.

Berdasarkan permasalahan diatas, maka perlu dilakukan pemanfaatan pelayanan yang berhubungan dengan kontrasepsi KB pada PUS di Puskesmas Tamalanrea Makassar dan diharapkan hasil penelitian dapat digunakan sebagai solusi untuk mengatasi permasalahan yang ada di Puskesmas Tamalanrea Makassar.

\section{B. Rumusan Masalah}

Berdasarkan latar belakang masalah tersebut diatas, maka rumusan masalah pada penelitian ini adalah apakah ada faktor yang berhubungan dengan pemanfaatan pelayanan alat kontrasepsi keluarga berencana (KB) pada pasangan usia subur (PUS) di puskesmas tamalanrea?

\section{Tujuan Penelitian}

1. Tujuan umum

Untuk mengetahui faktor yang berhubungan dengan pemanfaatan pelayanan alat kontrasepsi keluarga berencana pada pasangan usia subur di puskesmas Tamalanrea.

2. Tujuan khusus

a. Untuk mengetahui hubungan umur dengan pemanfaatan pelayanan alat kontrasepsi keluarga berencana pada pus.

b. Untuk mengetahui hubungan tingkat pengetahuan dengan pemanfaatan pelayanan alat kontrasepsi keluarga berencana pada pus.

c. Untuk mengetahui hubungan tingkat pendidikan dengan pemanfaatan pelayanan alat kontrasepsi keluarga berencana pada pus.

d. Untuk mengetahui hubungan status pekerjaan dengan pemanfaatan pelayanan alat kontrasepsi keluarga berencana pada pus.

e. Untuk mengetahui hubungan pemberian informasi alat kontrasepsi dengan pemanfaatan pelayanan alat kontrasepsi keluarga berencana pada pus.

f. Untuk mengetahui hubungan dukungan suami dengan pemanfaatan pelayanan alat kontrasepsi keluarga berencana pada pus.

\section{Manfaat Penelitian}

1. Manfaat Praktis

Hasil penelitian ini merupakan suatu sumber informasi yang penting bagi Puskesmas Tamalanrea dalam hal meningkatkan pelayanan keluarga 
berencana pada pasangan usia subur di puskesmas.

2. Manfaat Ilmiah

Penelitian ini diharapakan dapat menambah khazanah ilmu pengetahuan, khususnya dalam bidang kesehatan masyarakat dan dijadikan sebagai sumber referensi bagi penelitian selanjutnya.

\section{METODE PENELITIAN}

\section{A. Jenis Penelitian}

Metode penelitian yang digunakan adalah penelitian kuantitatif dengan pendekatan cross sectional study yang dimaksudkan untuk mengetahui dinamika hubungan antara variabel independen dengan variabel dependen.

\section{B. Waktu dan Tempat Penelitian}

Penelitian dilakukan pada bulan Maret 2019 di Wilayah Kerja Puskesmas Tamalanrea Kecamatan Tamalanrea Kota Makassar

\section{Populasi dan Sampel}

\section{Populasi}

Populasi dalam penelitian ini adalah semua pasangan usia subur yang diPuskesmas Tamalanrea Kota Makassar yang berjumlah 3332 orang.

2. Sampel

Sampel adalah bagian dari populasi yang akan di teliti sampel dalam penelitian ini adalah pasangan usia subur (PUS) di puskesmas Tamalanrea Kota Makassar.

Adapun besar sampel ditentukan dengan menggunakan rumus Slovin (Umar, 2003):

$$
\mathrm{n}=\frac{\ldots . \mathrm{N} \ldots .}{\left(1+\mathrm{Nd}^{2}\right)}
$$

Keterangan :

$$
\begin{aligned}
& \mathrm{N}=\text { Besar papulasi } \\
& \mathrm{n}=\text { Besar sampel } \\
& \mathrm{d}=\text { Tingkat kepercayaan } \\
& \text { di inginkan }(10 \%) \\
& \text { Jadi: } \\
& \mathrm{n}=\frac{\mathrm{N}}{\left(1+\mathrm{Nd}^{2}\right)} \\
& \mathrm{n}=\frac{3332}{\left(1+3332(0,1)^{2}\right)} \\
& \mathrm{n}=97
\end{aligned}
$$$$
\mathrm{d}=\text { Tingkat kepercayaan / ketepatan yang }
$$

3. Teknik pengambilan sampel

Metode pengambilan sampelmenggunakan cara non random sampling yaitu terhadap seluruh pasangan usai subur yang ada di wilayah kerja puskesmas tamalanrea yang menggunakan alat kontrasepsi KB.

\section{Metode Pengumpulan Data}

1. Data primer

Data primer diperoleh langsung kepada responden dengan menggunakan daftar pertanyaan yang telah disediakan. Dengan membagikan kuesioner yang berisi pertanyaan-pertanyaan terkait dengan penelitian yang telah disiapkan sebelumnya kepada pasangan usia subur yang memanfaatkan pelayanan alat kontrasepsi KB di puskesmas tamalanrea dan juga melakukan door to door untuk mengetahui tanggapan dan persepsi terhadap variabel yang diteliti.

2. Data Sekunder

Data Sekunder diperoleh langsung di puskesmas dan unit yang terkait dengan objek penelitian,serta di peroleh dari dokumentasi serta data yang lain yang dapat menunjang penulisan ini.

\section{E. Pengolahan dan Analisis Data}

Pengolahan data dilakukan menggunakan aplikasi program SPSS. Dengan langkah pengolahan data sebagai berikut :

1. Pengolahan Data

\section{a. Editing}

Data yang didapat selama penelitian diperiksa kelengkapannya terlebih dahulu.

\section{b. Coding}

Apabila semua data telah dikumpuldan selesai di edit,kemudianakan dilakukan pengkodean data berdasarkan buku kode yang telah disusun sebelumnya dan telah dipindahkan ke format aplikasi program SPSS di komputer.

c. Entry data

Memasukkan data kedalam program SPSS untuk masing-masing variabel. Urutan data berdasarkan nomor responden dalam kuesioner.

d. Cleaning data

Memeriksa semua lembar kerja untuk membersikan kesalahan yang mungkin terjadi selama proses input data. Proses ini dilakukan untuk melalui analisis frekuensi pada semua variable. Data missing dibersihkan dengan menginput data yang benar.

2. Analisis Data

Proses analisis data dilakukan dengan menggunakan program analisis data yang telah tersedia dalam program SPSS, baik analisis univariat maupun bivariat.

a. AnalisisUnivariat

Analisis univariat dilakukan pada setiap variable yang telah diteliti dengan menggunakananalisis frekuensi setiap sehinggamenghasilkan distribusi dan persentase dari setiap variable yang telah diteliti. 
b. Analisis Bivariat

Analisis bivariat dilakukan dengan menggunakan Uji Chi Square untuk melihat ada atau tidak hubungan antara variebel independen dan variabel dependen yang telah di teliti. Interprestasi dari hasil analisisUji Chi Sguare sebagai berikut :

Jika nilia $\mathrm{p}>\alpha(0,05)$ maka hipotesis penelitian (Ha) ditolak

Jika nilai $\mathrm{p} \leq \alpha(0,05)$ maka hipotesis penelitian (Ha) diterima

\section{F. Penyajian Data}

Data yang diolah, disajikan dalam bentuk tabel distribusi frekuensi dan persentase di sertai penjelasannya, selain itu juga dilakukan dalam bentuk tabel analisis dengan narasi sebagai penjelasan.

\section{HASIL DAN PEMBAHASAN}

\section{A. Hasil Penelitian}

Penelitian ini dilakukan di Puskesamas Tamalanrea Kecamatan Makassar Kota Makassar Sulawesi Selatan.Pengumpulan data dilakukan pada bulan Maret 2019. Pengumpulan data dilakukan secara primer, yaitu dengan melakukan wawancara terstruktur menggunakan kuesioner pada responden yang dilakukan di lapangan.Jumlah responden dalam penelitian ini adalah 97 responden. Data yang telah dikumpulkan kemudian diolah dan dianalisis sehingga di peroleh hasil penelitian yang disajikan dalam bentuk tabel yang disertai narasi sebagai berikut:

\section{Analisis Univariat}

Analisis univariat dilakukan untuk mengetahui distribusi frekuensi dari setiap variebel yang diteliti. Kemudian ditampilkan dalam bentuk tabel sebagai berikut:

a. Karakteristik Responden

Karakteristik responden terdiri dari atas umur, pekerjaan, dan pendidikan serta alat kontrasepsi yang digunakan oleh responden. Informasi karakteristik responden akan disajikan pada Tabel

Tabel I. Distribusi karasteristik responden di Puskesmas Tamalanrea Kota Makassar Tahun 2019.

\begin{tabular}{lcc}
\hline \multicolumn{1}{c}{ Kelompok Responden } & n & \% \\
\hline Umur & & \\
$\quad<20$ & 8 & 8,2 \\
$20-35$ & 61 & 62,9 \\
$\quad>35$ & 28 & 28,9 \\
Pekerjaan & & \\
$\quad$ Mahasiswa/Pelajar & 10 & 10,3 \\
PNS & 12 & 12,4 \\
Pegawai & 19 & 19,6 \\
IRT/Tidak bekerja & 20 & 20,6 \\
\hline
\end{tabular}

\begin{tabular}{lcc}
\hline Pendidikan & & \\
Tamat SMP & 44 & 45,4 \\
Tamat SMA & 41 & 43,3 \\
Diploma & 6 & 6,2 \\
Tamat Perguruan Tinggi & 6 & 6,2 \\
\hline Total & 97 & 100,0 \\
\hline Sumber : Data Primer 2019 & &
\end{tabular}

Tabel I menunjukkan bahwa berdasarkan pekerjaan, sebanyak 36 responden dengan pekerjaan sebagai IRT (Ibu Rumah Tangga) menggunakan alat kontrasepsi. Jika dilihat dari kelompok umur, maka paling banyak responden yang berada pada kelompok umur 20-35 tahun yang memanfaatkan alat kontrasepsi KB yakni sebanyak 61 responden,di bandingkan dengan responden pada kelompok umur $<20$ tahun yakni hanya 8 responden yang memanfaatkan alat kontrasepsi KB. Berdasarkan pendidikan terakhir responden, paling banyak responden yang memanfaatkan alat kontrasepsi KB adalah responden yang tamat SMP yakni sebanyak 44 responden.

Sedangkan yang memiliki pendidikan rendah yaitu Diploma dan Perguruan tinggi sebanyak 6 responden.

1. Umur

Kelompok umur responden dibagi dalam 3 kategori yaitu $<20$ tahun, 20-35 tahun, dan $>35$ tahun. Hasil penelitian dapat dilihat pada tabel II sebagai berikut:

Tabel II. Distribusi Frekuensi Responden Berdasarkan Umur di Puskesmas Tamalanrea Kota Makassar Tahun 2019

\begin{tabular}{ccc}
\hline $\begin{array}{c}\text { Kelompok } \\
\text { Umur (Tahun) }\end{array}$ & $\begin{array}{c}\text { Frekuensi } \\
(\mathbf{n})\end{array}$ & $\begin{array}{c}\text { Presentase } \\
(\mathbf{\%})\end{array}$ \\
\hline$<20$ & 8 & 8,2 \\
\hline $20-35$ & 61 & 62.9 \\
\hline$>35$ & 28 & 28.8 \\
\hline Total & 97 & 100.0 \\
\hline Sumber : Data Primer, 2019 &
\end{tabular}

Berdasarkan Tabel II menunjukkan bahwa dari 97 responden berdasarkan kelompok umur yang paling banyak yaitu pada kelompok mur 20-35 tahun sebanyak 61 orang $(62.9 \%)$ dan yang paling sedikit yaitu pada kelompok umur $<20$ tahun sebanyak 8 orang $(8.2 \%)$.

2. Pengetahuan

Berdasarkan hasil penelitian maka diperoleh tabel distribusi frekuensi tingkat pengetahun yang diuraikan sebagai berikut :

Tabel III. Distribusi Frekuensi Responden Berdasarkan Pengetahuan Tentang 
Alat Kontrasepsidi Puskesmas Tamalanrea Kota Makassar Tahun 2019

\begin{tabular}{ccc}
\hline Pengetahuan & $\begin{array}{c}\text { Frekuensi } \\
(\mathbf{n})\end{array}$ & $\begin{array}{c}\text { Presentase } \\
(\boldsymbol{\%})\end{array}$ \\
\hline Cukup & 63 & 64,9 \\
Kurang & 34 & 35,1 \\
\hline Total & 97 & 100.0 \\
\hline
\end{tabular}

Sumber : Data Primer, 2019

Berdasarkan tabel III dapat dilihat bahwa dari 97 responden yang memiliki pengetahuan cukup sebanyak 63 orang $(64,9 \%)$ sedangkan yang pengetahuan kurang sebanyak 34 orang $(35,1 \%)$.

3. Pendidikan

Berdasarkan hasil penelitian maka diperoleh tabel distribusi frekuensi berdasarkan tingkat pendidikan yang diuraikansebagai berikut:

Tabel IV. Distribusi Frekuensi Responden Berdasarkan Tingkat Pendidikandi Puskesmas Tamalanrea Kota Makassar Tahun 2018

\begin{tabular}{ccc}
\hline Pendidikan & Frekuensi (n) & Presentase $(\boldsymbol{\%})$ \\
\hline Tinggi & 53 & 54.6 \\
Rendah & 44 & 45,4 \\
\hline Total & 97 & 100.0 \\
\hline
\end{tabular}

Sumber : Data Primer, 2019

Berdasarkan Tabel IV menunjukkan bahwa dari 97 responden dengan tingkat pendidikan yang tinggi sebanyak 53orang $(54.6 \%)$ sedangkan pendidikan rendah sebanyak 44 orang $(45.4 \%)$.

4. Pekerjaan

Berdasarkan hasil penelitian maka diperoleh tabel distribusi frekuensi pekerjaan yang diuraikan sebagai berikut:

Tabel V. Distribusi Frekuensi Responden Berdasarkan Pekerjaan di Puskesmas Tamalanrea Kota Makassar Tahun 2018

\begin{tabular}{ccc}
\hline Pekerjaan & Frekuensi (n) & Presentase (\%) \\
\hline Bekerja & 56 & 57.7 \\
Tidak Bekerja & 41 & 42,3 \\
\hline Total & 97 & 100.0 \\
\hline
\end{tabular}

Sumber : Data Primer, 2019

Berdasarkan tabel $\mathrm{V}$, dapat dilihat bahwa dari 97 responden yang bekerja sebanyak 56 orang $(57,7 \%)$ sedangkan yang tidak bekerja sebanyak 41 orang $(42,3 \%)$.

5. Pemberian informasi

Berdasarkan hasil penelitian maka diperoleh tabel distribusi frekuensi tingkat pengetahun yang diuraikan sebagai berikut:

Tabel VI. Distribusi Frekuensi Responden Berdasarkan Pemberian Informasi di Puskesmas Tamalanrea Kota

Makassar Tahun 2018

\begin{tabular}{ccc}
\hline $\begin{array}{c}\text { Pemberian } \\
\text { informasi }\end{array}$ & Frekuensi (n) & Presentase (\%) \\
\hline Pernah & 51 & 52.6 \\
Tidak Pernah & 46 & 47,4 \\
\hline Total & 97 & 100.0 \\
\hline \multicolumn{2}{c}{ Sumber : Data Primer, 2019 }
\end{tabular}

Berdasarkan tabel VI dapat dilihat bahwa dari 97 responden yang pernah mendapat informasi sebanyak 51 orang $(52,6 \%)$ sedangkan yang tidak pernah mendapat informasi sebanyak 46 orang $(47,4 \%)$.

6. Dukungan suami

Berdasarkan hasil penelitian maka diperoleh tabel distribusi frekuensi tingkat pengetahun yang diuraikan sebagai berikut:

Tabel VII. Distribusi Frekuensi Responden Berdasarkan Dukungan Suami di Puskesmas Tamalanrea Kota Makassar Tahun 2018

\begin{tabular}{ccc}
\hline Dukungan & Frekuensi (n) & Presentase $\mathbf{( \% )}$ \\
\hline Mendukung & 59 & 60.8 \\
Tidak & 38 & 39,2 \\
Mendukung & & \\
\hline Total & 97 & 100.0 \\
\hline
\end{tabular}

Sumber : Data Primer, 2019

Berdasarkan tabel VII, dapat dilihat bahwa dari 97 responden yang suaminya mendukung sebanyak 59 orang $(60,8 \%)$ sedangkan yang suami yang tidak mendukung sebanyak 38 orang $(39,2 \%)$.

\section{Analisis Bivariat}

a. Variabel Umur dengan pemenfaatan pelayanan alat kontrasepsi KB

Untuk mengetahui hubungan antara faktor umur dengan pemenfaatan pelayanan alat kontrasepsi $\mathrm{KB}$ dapat di lihat pada tabel berikut.

Tabel VIII. Hubungan antara Umur dengan Pemanfaatan Pelayanan Alat Kontrasepsi KB pada PUS di Puskesmas Tamalanrea Kota Makassar Tahun 2018

\begin{tabular}{|c|c|c|c|c|c|c|c|}
\hline \multirow{3}{*}{$\begin{array}{c}\text { Kelompok } \\
\text { Umur } \\
\text { (Tahun) }\end{array}$} & \multicolumn{4}{|c|}{$\begin{array}{c}\text { Pemenfaatan Pel. Alat Kontrasepsi } \\
\text { KB Pada PUS }\end{array}$} & \multirow[t]{3}{*}{$\mathbf{N}$} & \multirow[t]{3}{*}{$\%$} & \multirow[t]{3}{*}{$\begin{array}{c}\text { Uji } \\
\text { statistik }\end{array}$} \\
\hline & \multicolumn{2}{|c|}{ Memanfaatkan } & \multicolumn{2}{|c|}{$\begin{array}{c}\text { Tidak } \\
\text { Memanfaatkan }\end{array}$} & & & \\
\hline & $\mathbf{n}$ & $\%$ & $\mathbf{n}$ & $\%$ & & & \\
\hline$<20$ & 5 & 62,5 & 3 & 37,5 & 8 & 100 & $\mathrm{P}=0,009$ \\
\hline $20-35$ & 36 & 59,0 & 25 & 41,0 & 61 & 100 & $\omega=0,016$ \\
\hline$>35$ & 25 & 89,3 & 3 & 10,7 & 28 & 100 & \\
\hline Total & 66 & 68,0 & 31 & 2,0 & 97 & 100 & \\
\hline
\end{tabular}

Berdasarkan tabel VIII menunjukkan bahwa dari 97 responden yang memiliki umur $<20$ dan 
memanfaatkan alat kontrasepsi $\mathrm{KB}$ sebanyak 5 orang $(62,5 \%)$ dan responden yang tidak menggunakan alat kontrasepsi $\mathrm{KB}$ sebanyak 3 orang $(37,5 \%)$. Sedangkan yang memiliki umur 20-35 dan memanfaatkan alat kontrasepsi KB sebanyak 36 orang $(59,0 \%)$ dan yang tidak memanfaatkan alat kontrasepsi KB sebanyak 25 orang $(41,0 \%)$ dan yang memiliki umur $>35$ dan memanfaatkan alat kontrasepsi KB sebanyak 25 orang $(89,0)$ dan yang tidak memanfaatkan alat kontrasepsi KB sebanyak 3 orang $(10,7)$. Hasil analisis dengan menggunakan Chi Square diperoleh nilai $P$ Value $=0,009$ atau nilai $\mathrm{P}<$ 0,05. Dengan demikian, maka Ho ditolak dan Ha diterima berarti ada hubungan antara umur dengan pemanfaatan pelayanan alat kontrasepsi KB di Puskesmas Tamalanrea. Hasil uji koefisien phi $(\oplus)$ diperoleh nilai $\omega=0,016$. Ini menunjukkan bahwa kekuatan hubungan lemah karena nilai phi berada di antara 0,01-0,25, yang artinya hubungan antara umur dengan pemanfaatan pelayanan alat kontrasepsi $\mathrm{KB}$ bersifat lemah.

b. Variabel pengetahuan dengan pemanfaatan pelayanan alat kontrasepsi $\mathrm{KB}$

Untuk mengetahui hubungan antara pengetahuan dengan pemanfaatan pelayana alat kontrasepsi $\mathrm{KB}$ dapat di lihat pada tabel berikut :

Tabel IX. Hubungan antara Pengetahuan dengan Pemanfaatan PelayananAlat Kontrasepsi KB pada PUS di Puskesmas Tamalanrea Kota Makassar Tahun 2018

\begin{tabular}{|c|c|c|c|c|c|c|c|}
\hline \multirow[t]{3}{*}{$\begin{array}{l}\text { Pengeta } \\
\text { huan }\end{array}$} & \multicolumn{4}{|c|}{$\begin{array}{c}\text { Pemenfaatan Pel. Alat Kontrasepsi } \\
\text { KB Pada PUS }\end{array}$} & \multirow[t]{3}{*}{$\mathbf{N}$} & \multirow[t]{3}{*}{$\%$} & \multirow{3}{*}{$\begin{array}{c}\text { Uji } \\
\text { statis } \\
\text { tik }\end{array}$} \\
\hline & \multicolumn{2}{|c|}{ Memanfaatkan } & \multicolumn{2}{|c|}{$\begin{array}{c}\text { Tidak } \\
\text { Memanfaatkan }\end{array}$} & & & \\
\hline & $\mathbf{n}$ & $\%$ & $\mathbf{n}$ & $\%$ & & & \\
\hline Cukup & 41 & 71,9 & 16 & 28,1 & 57 & 100 & $\mathrm{P}=0$ \\
\hline Kurang & 25 & 62,5 & 15 & 37,5 & 40 & 100 & 448 \\
\hline Total & 66 & 68,0 & 31 & 32,0 & 97 & 100 & $\begin{array}{c}\oplus= \\
0,016\end{array}$ \\
\hline
\end{tabular}

Sumber : Data Primer, 2019

Berdasarkan tabel IX menunjukkan bahwa dari 97 responden yang memiliki pengetahuan cukup dan memanfaatkan pelayanan alat kontrasepsi KB sebanyak 41 orang $(71.9 \%)$ dan responden yang tidak memanfaatkan pelayanan alat kontrasepsi KB sebanyak orang 16 (28.1\%). Sedangkan yang memiliki pengetahuan kurang dan memanfaatkan pelayanan alat kontrasepsi KB sebanyak 25 orang $(62,5 \%)$ dan yang tidak memanfatkan pelayanan alat kontrasepsi KB sebanyak15 orang $(37,5 \%)$. Hasil analisis dengan menggunakan Chi Square diperolehnilai $P$ Value $=0,448$ atau nilai $\mathrm{P}>0,05$. Dengan demikian, maka Ho diterima dan $\mathrm{Ha}$ ditolak berarti tidak ada hubungan antara pengetahuan dengan pemanfaatan pelayanan alat kontrasepsi $\mathrm{KB}$ di Puskesmas Tamalanrea. Hasil uji koefisien phi $(\varphi)$ diperoleh nilai $\omega=0,100$. Ini menunjukkan bahwa kekuatan hubungan lemah karena nilai phi berada di antara 0,010,25 , yang artinya hubungan antara umur dengan pemanfaatan pelayanan alat kontrasepsi KB bersifat lemah.

c. Variabel Pendidikan dengan Pemanfaatan Pelayanan alat kontrasepsi KB

Untuk mengetahui hubungan antara faktor pendidikan dengan pemanfaatan pelayanan alat kontrasepsi $\mathrm{KB}$ dapat dilihat pada tabel berikut :

Tabel X. Hubungan antara Pendidikan dengan Pemanfaatan Pelayanan Alat Kontrasepsi KB pada PUS di Puskesmas Tamalanrea Kota Makassar Tahun 2018

\begin{tabular}{|c|c|c|c|c|c|c|c|}
\hline \multirow[t]{3}{*}{ Pendidikan } & \multicolumn{4}{|c|}{$\begin{array}{l}\text { Pemenfaatan Pel. Alat Kontrasepsi KB } \\
\text { Pada PUS }\end{array}$} & \multirow[t]{3}{*}{$\mathbf{N}$} & \multirow[t]{3}{*}{$\%$} & \multirow{3}{*}{$\begin{array}{c}\text { Uji } \\
\text { Statis } \\
\text { tik }\end{array}$} \\
\hline & \multicolumn{2}{|c|}{ Memanfaatkan } & \multicolumn{2}{|c|}{$\begin{array}{c}\text { Tidak } \\
\text { Memanfaatkan }\end{array}$} & & & \\
\hline & $\mathbf{n}$ & $\%$ & $\mathbf{n}$ & $\%$ & & & \\
\hline Tinggi & 31 & 58,5 & 22 & 41,5 & 54 & 100 & $\mathrm{P}=$ \\
\hline Rendah & 35 & 79,5 & 9 & 20,5 & 44 & 100 & 0,446 \\
\hline Total & 66 & 68,0 & 31 & 32,0 & 97 & 100 & $\begin{array}{c}\varphi= \\
0,225\end{array}$ \\
\hline
\end{tabular}

Berdasarkan tabel X menunjukkan bahwa dari 97 responden yang memiliki pendidikan yang tinggi dan memanfaatkan pelayanan alat kontrasepsi $\mathrm{KB}$ sebanyak 31 orang $(58.5 \%)$ dan responden yang tidak memiliki pendidikan yang tinggi dan tidak memanfaatkan pelayanan alat kontrasepsi KB sebanyak 22 orang (41.5\%). Sedangkan yang memiliki pendidikan yang rendah dan memanfaatkan pelayanan alat kontrasepsi KB sebanyak 35 orang $(79.5 \%)$ dan yang memiliki pendidikan yang rendah dan tidak memanfaatkan pelayanan alat kontrasepsi KBsebanyak 9 orang (20.5\%). Hasil analisis dengan menggunakan Chi Square diperolehnilai $P$ Value $=0,046$ atau nilai $\mathrm{P}>$ 0,05. Dengan demikian, maka Ho ditolak dan Ha diterima berarti ada hubungan antara pendidikan dengan pemanfaatan pelayanan alat kontrasepsi KB di Puskesmas Tamalanrea. Hasil uji koefisien phi ( () diperoleh nilai $\omega=0,225$. Ini menunjukkan bahwa kekuatan hubungan lemah karena nilai phi berada di antara 0,01-0,25, yang artinya hubungan antara pendidikan dengan pemanfaatan pelayanan alat kontrasepsi $\mathrm{KB}$ bersifat lemah.

d. Variabel pekerjaan dengan Pemanfaatan Pelayanan alat kontrasepsi KB

Untuk mengetahui hubungan antara faktor pendidikan dengan pemanfaatan 
pelayanan alat kontrasepsi $\mathrm{KB}$ dapat dilihat pada tabel berikut:

Tabel XI. Hubungan antara Pekerjaan dengan Pemanfaatan Pelayanan Alat Kontrasepsi KB pada PUS di Puskesmas Tamalanrea Kota Makassar Tahun 2016

\begin{tabular}{|c|c|c|c|c|c|c|}
\hline \multirow{3}{*}{ Pekerjaan } & \multicolumn{3}{|c|}{$\begin{array}{c}\text { Pemenfaatan Pel. Alat } \\
\text { Kontrasepsi KB Pada PUS }\end{array}$} & \multirow{3}{*}{$\mathbf{N}$} & \multirow{3}{*}{$\%$} & \multirow{3}{*}{$\begin{array}{c}\mathbf{U j i} \\
\text { statist } \\
\mathbf{k}\end{array}$} \\
\hline & Memanfaatkan & \multicolumn{2}{|c|}{$\begin{array}{c}\text { Tidak } \\
\text { Memanfaatkan } \\
\end{array}$} & & & \\
\hline & $\%$ & n & $\%$ & & & \\
\hline Bekerja & 73,2 & 15 & 26,8 & 56 & 100 & $\mathrm{P}=$ \\
\hline $\begin{array}{l}\text { Tidak } \\
\text { Bekerja }\end{array}$ & 61,0 & 16 & 39,0 & 41 & 100 & $\begin{array}{c}0,291 \\
\varphi=\end{array}$ \\
\hline Total & 68,0 & 31 & 32,0 & 97 & 100 & 0,130 \\
\hline
\end{tabular}

Berdasarkan tabel XI menunjukkan bahwa dari 97 responden yang memiliki yang bekerjadan memanfaatkan pelayanan alat kontrasepsi KB sebanyak 41 orang (73.2\%) dan responden yangtidak bekerja dan memanfaatkan pelayanan alat kontrasepsi KB sebanyak 25 orang (61.0\%). Sedangkan yang memiliki pekerjaan dan tidak memanfaatkan pelayanan alat kontrasepsi KB sebanyak 15 orang (26.8\%) dan yang tidak memiliki pekerjaan dan tidak memanfaatkan pelayanan alat kontrasepsi KB sebanyak 16 orang (39.0\%).Hasil analisis dengan menggunakan Chi Square diperoleh nilai $P$ Value $=0,29$ atau nilai $\mathrm{P}>$ 0,05 . Dengan demikian, maka Ho diterima dan Ha ditolak berarti tidak ada hubungan antara pekerjaan dengan pemanfaatan pelayanan alat kontrasepsi KB di Puskesmas Tamalanrea. Hasil uji koefisien phi $(\varphi)$ diperoleh nilai $\omega=0,130$. Ini menunjukkan bahwa kekuatan hubungan lemah karena nilai phi berada di antara 0,01-0,25, yang artinya hubungan antara pendidikan dengan pemanfaatan pelayanan alat kontrasepsi $\mathrm{KB}$ bersifat lemah.

e. Variabel pemberian informasi dengan Pemanfaatan Pelayanan alat kontrasepsi KB Untuk mengetahui hubungan antara faktor pendidikan dengan pemanfaatan pelayanan alat kontrasepsi $\mathrm{KB}$ dapat dilihat pada tabel berikut :

Tabel XII. Hubungan antara Pemberian informasidengan Pemanfaatan Pelayanan Alat Kontrasepsi KB pada PUS di Puskesmas Tamalanrea Kota Makassar Tahun 2018

\begin{tabular}{|c|c|c|c|c|c|c|c|}
\hline Pernah & 40 & 78,4 & 11 & 21,6 & 51 & 100 & $\mathrm{P}=$ \\
\hline $\begin{array}{l}\text { Tidak } \\
\text { pernah }\end{array}$ & 26 & 56,5 & 20 & 43,5 & 46 & 100 & $\begin{array}{c}0,036 \\
\omega=\end{array}$ \\
\hline Total & 66 & 68,0 & 31 & 32,0 & 97 & 100 & 0,235 \\
\hline
\end{tabular}

Berdasarkan tabel XII menunjukkan bahwa dari 97 responden yang memiliki pemberian informasi dan pernah memanfaatkan pelayanan alat kontrasepsi KB sebanyak 40 orang $(78.4 \%)$ dan responden yang tidak memiliki pemberian informasidan pernah tidak memanfaatkan pelayanan alat kontrasepsi KB sebanyak 11 orang (21.6\%). Sedangkan yang memiliki pemberian informasi yang tidak pernah memanfaatkan pelayanan alat kontrasepsi KB sebanyak 26 orang $(56.5 \%)$ dan yang memiliki pemberian informasi yang tidak pernah dan tidak memanfaatkan pelayanan alat kontrasepsi KBsebanyak 20 orang (43.5\%). Hasil analisis dengan menggunakan Chi Square diperoleh nilai $P$ Value $=0,036$ atau nilai $\mathrm{P}$ $<0,05$. Dengan demikian, maka Ho ditolak dan Ha diterima berarti ada hubungan antara pemberian informasi dengan pemanfaatan pelayanan alat kontrasepsi KBdi Puskesmas Tamalanrea. Hasil uji koefisien phi ( () diperoleh nilai $\omega=0,235$. Ini menunjukkan bahwa kekuatan hubungan lemah karena nilai phi berada di antara 0,01-0,25, yang artinya hubungan antara pendidikan dengan pemanfaatan pelayanan alat kontrasepsi $\mathrm{KB}$ bersifat lemah.

f. Variabel dukungan suami dengan Pemanfaatan Pelayanan alatkontrasepsi KB Untuk mengetahui hubungan antara faktor pendidikan dengan pemanfaatan pelayanan alat kontrasepsi $\mathrm{KB}$ dapat dilihat pada tabel berikut:

Tabel XIII. Hubungan antara Dukungan Suami dengan Pemanfaatan Pelayanan Alat Kontrasepsi KB pada PUS di Puskesmas Tamalanrea Kota Makassar Tahun 2018

\begin{tabular}{|c|c|c|c|c|c|c|c|}
\hline \multirow[t]{3}{*}{$\begin{array}{l}\text { Dukungan } \\
\text { suami }\end{array}$} & \multicolumn{4}{|c|}{$\begin{array}{c}\text { Pemenfaatan Pel. Alat } \\
\text { Kontrasepsi KB Pada PUS }\end{array}$} & \multirow[t]{3}{*}{$\mathbf{N}$} & \multirow[t]{3}{*}{$\%$} & \multirow{3}{*}{$\begin{array}{c}\text { Uji } \\
\text { statis } \\
\text { tik }\end{array}$} \\
\hline & \multicolumn{2}{|c|}{ Memanfaatkan } & \multicolumn{2}{|c|}{$\begin{array}{c}\text { Tidak } \\
\text { Memanfaatkan }\end{array}$} & & & \\
\hline & $\mathbf{n}$ & $\%$ & $\mathbf{n}$ & $\%$ & & & \\
\hline Mendukung & 35 & 59,3 & 24 & 18,9 & 59 & 100 & $\begin{array}{c}\mathrm{P}= \\
0,448\end{array}$ \\
\hline $\begin{array}{l}\text { Tidak } \\
\text { mendukung }\end{array}$ & 31 & 81,6 & 7 & 18,4 & 38 & 100 & $\begin{array}{c}\omega= \\
0,016\end{array}$ \\
\hline Total & 66 & 68,0 & 31 & 32,0 & 97 & 100 & \\
\hline
\end{tabular}

Sumber : Data Primer, 2019

\begin{tabular}{|c|c|c|c|c|c|c|}
\hline \multirow[t]{3}{*}{$\begin{array}{c}\text { Pemberian } \\
\text { informasi }\end{array}$} & \multicolumn{2}{|c|}{$\begin{array}{c}\text { Pemenfaatan Pel. Alat Kontrasepsi } \\
\text { KB Pada PUS }\end{array}$} & \multirow{3}{*}{$\mathbf{N}$} & \multirow{3}{*}{$\%$} & \multirow{3}{*}{$\begin{array}{c}\mathrm{Uji} \\
\text { statistik }\end{array}$} & \multirow{3}{*}{$\begin{array}{l}\text { Berdasarkan tabel XIII menunjukkan bahwa } \\
\text { dari } 97 \text { responden yang memiliki dukungan } \\
\text { suamidan memanfaatkan pelayanan alat } \\
\text { kontrasepsi KB sebanyak } 35 \text { orang }(59.3 \%)\end{array}$} \\
\hline & Memanfaatkan & Tidak & & & & \\
\hline & 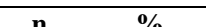 & & & & & \\
\hline
\end{tabular}


dan responden yang tidak memiliki dukungan suami dan memanfaatkan pelayanan alat kontrasepsi $\mathrm{KB}$ sebanyak 31 orang (81.6\%). Sedangkan yang tidak mendapat dukungan suami dan tidak memanfaatkan pelayanan alat kontrasepsi KB sebanyak 24 orang $(40.7 \%)$ dan yang tidak mendapat dukung suami dan tidak memanfaatkan pelayanan alat kontrasepsi KB sebanyak 7 orang (18.4\%). Hasil analisis dengan menggunakan Chi Square diperoleh nilai $P$ Value $=0,038$ atau nilai $\mathrm{P}<0,05$. Dengan demikian, maka Ho ditolak dan Ha diterima berarti ada hubungan antara dukungan suami dengan pemanfaatan pelayanan alat kontrasepsi KB di Puskesmas Tamalanrea. Hasil uji koefisien phi $(\varphi)$ diperoleh nilai $\omega=0,233$. Ini menunjukkan bahwa kekuatan hubungan lemah karena nilai phi berada di antara 0,01-0,25, yang artinya hubungan antara pendidikan dengan pemanfaatan pelayanan alat kontrasepsi KB bersifat lemah.

\section{B. Pembahasan}

Untuk mengetahui lebih lanjut hasil penelitian yang di peroleh setelah dilakukan pengolahan, penyajian data, maka akan dibahas sesuai dengan variabel yang di teliti sebagai berikut:

1. Hubungan antara umur dengan pemanfaatan pelayanan alat kontrasepsi $\mathrm{KB}$

Umur adalah usia ibu yang secara garis besar menjadi indikator dalam kedewasaan dalam setiap pengambilan keputusan yang mengacu pada setiap pengalaman. Usia yang cukup dalam mengawali atau memasuki masa perkawinan dan kehamilan akan membantu seseorang dalam kematangan dalam menghadapi persoalan atau masalah, dalam hal ini keputusan untuk menggunakan alat kontrasepsi setelah melahirkan. Demikian sebaliknya dengan usia kurang dari 16 tahun maka kemungkinan kematangan pikiran dan perilaku juga kurang terlebih menghadapi perubahan dan adaptasi setelah melahirkan (Kartika, 2014).

Bila di tinjau dari penggunaan kontrasepsi maka masa pencegahan kehamilan umur $<20$ tahun seseorang dianjurkan untuk memilih alat kontrasepsi yang disarankan seperti pil, IUD, kondom yang merupakan alat yang baik digunakan untuk menjarangkan kehamilan. Pada masa menjarangkan kehamilan umur 2035 tahun dianjurkan untuk memilih alat kontrasepsi yang disarankan IUD, pil, suntikan, implant. Pada masa ingin mengakhiri kehamilan umur $>35$ tahun dianjurkan untuk memilih alat kontrasepsi yang disarankan yaitu IUD, implant, suntikan, pil, dan kondom.Dengan demikian umur akan menentukan dalam pemilihan alat kontrasepsi.

Hasil penelitian ini menunjukkan bahwa ada hubungan antara umur dengan pemanfaatan pelayanana alat kontrasepsi $\mathrm{KB}$ pada pasangan usia subur di puskesmas tamalanrea dengan $\mathrm{P}<$ 0.05 yaitu sebesar 0,009 . Penelitian ini sejalan dengan penelitian Grestasari (2014) yang menunjukkan bahwa ada hubungan uisa dengan pemilihan jenis kontrasepsi.

Hasil penelitian yang dilakukan oleh Rahim (2014) menunjukkan bahwa dari hasil uji statistik menyatakan ada hubungan umur dengan penggunaan alat kontrasepsi.

2. Hubungan antara pengetahuan dengan pemanfaatan pelayanana alat kontrasepsi KB.

Pengetahuan merupakan seseorang yang memiliki pengetahuan tentang suatu alat kontrasepsi baik itu manfaat, efek samping, cara kerja maupun jenisnya akan teratur dan taat atas aturan penggunaannya.Begitu pula sebaliknya orang yang tidak tahu apapun tentang suatu alat kontrasepsi, lantas disuruh menggunakan, hal yang tidak kemungkin besar akan terjadi adalah salah dalam penggunaannya dan tidak sesuai aturan. Hasil penelitian ini menunjukkan bahwa tidak adanya hubungan antara pengetahuan dengan pemanfaatan pelayanan alat kontrasepsi.

Pasangan usai subur yang memiliki pengetahuan cukup akan memilih alat kontrasepsi motode jangka panjang karena pengetahuan peserta KB lebih sering mendapat informasi dari berbagai sumber seperti media sosial, elektronik, majalah dan sebagainya dan lebih banyak memanfaatkan pelayanan alat kontrasepsi dan pasangan usia subur yang tingkat pengetahuannya kurang sebagian besar menggunakan alat kontrasepsi dan memanfaatkan yaitu 25 (62.5\%), hal ini dikarenakan kurangnya pengetahuan tentang kontrasepsi terbatas dan hanya pada alat kontrasepsi yang digunakan pada pasangan usia subur. Sedangkan pasangan usia subur yang memiliki pengetahuan yang cukup dan tidak memanfaatkan pelayanan alat kontrasepsi bisa disebabkan oleh faktor lain dimana suami tidak mendukung untuk menggunakan alat kontrasepsi tersebut. Pasangan usia subur yang memiliki pengetahuan kurang karena beberapa hal yang mempengaruhi seperti informasi yang kurang mengenai alat kontrasepsi beserta efek sampingnya, sangat jarang mengikuti acaraacara penyuluhan mengenai keluarga berencana, namun tetap memanfaatkan pelayanan alat kontrasepsi kemungkinan adanya pemberian informasi dari orang lain baik itu dari keluarga maupun petugas kesehatan mengenai perlunya penggunaan alat kontrsepsi. Sedangkan pasangan usia subur yang pengetahuannya 
kurang dan tidak memanfaatkan pelayanan alat kontrasepsi bisa disebabkan karena ketidaktahuan pasangan usia subur (PUS) dalam penggunaan alat kontrasepsi. Bagi ibu yang kurang aktif dalam mengikuti kegiatan penyuluhan di daerah setempat diharapkan dapat berkonsultasi pada bidan tentang kontrasepsi yang cocok untuk digunakan baginya. Petugas kesehatan agar lebih sering melakukan penyuluhan tentang alat kontrasepsi kepada peserta KB.

3. Hubungan antara pendidikan dengan pemanfaatan pelayanan alat kontrasepsi KB

Pendidikan merupakan Tingkat pendidikan akan mempengaruhi wawasan dan pengetahuan ibu. Semakin rendah pendidikan ibu maka akses terhadap informasi tentang KB khususnya KB IUD akan berkurang sehingga ibu akan kesulitan untuk mengambil keputusan secara efektif, alat kontrasepsi yang mana akan dipilih oleh ibu.

Pada era sekarang ini soerang istri mempunyai peran ganda di satu pihak sebagai ibu rumah tangga dan harus bertanggung jawab atas kesejahteraan anak keluarga namun disisi lain diharapkan dapat berperan aktif dalam berbagai kegiatan masyarakat. Untuk meningkatkan kesejahteraan dan keterampilan diberbagai bidang yang sangat diperlukan.

Yanuar (2010) mengemukakan bahwa pendidikan merupakan salah satu faktor yang menentukan pemilihan suatu metode kontrasepsi karena tingkat pendidikan yang lebih tinggi mampu menyerap informasi dan lebih mampu mempertimbangkan hal-hal yang menguntungkan atau efek samping bagi kesehatan yang berhubungan dengan pemakaian suatu metode kontrasepsi(Widyastuti, 2011).

Hasil penelitian ini menunjukkan bahwa ada hubungan antara pendidikan dengan pemanfaatan pelayanan alat kontrasepsi KB. Dari hasil analisis menunjukkan bahwa pasangan usia subur yang memiliki pendidikan tinggi lebih sedikit memanfaatkan pelayananan alat kontrasepsi $\mathrm{KB}$, Sedangkan pasangan usia subur yang memiliki pendidikan rendah lebih banyak memanfaatkan pelayanan alat kontrasepsi KB, hal ini berarti terdapat kecenderungan bahwa pendidikan tinggi seseorang akan berpengaruh terhadap pemakaian alat kontrasepsi KB.

Hasil penelitian oleh Nazilah (2012) ini diketahuai bahwa perempuan yang pernah kawin usia 15-49 tahun di NTT yang memakai kontrasepsi sebagian besar pendidikan SMA yaitu sebesar $82,9 \%$. Uji statistik menunjukkan bahwa ada hubungan antara pendidikan responden dengan penggunaaa kontrasepsi. Semakin tinggi pendididkan seseorang perempuan maka cenderung untuk menggunkan kontrasepsi. Sejalan dengan penelitian Awalina, 2006. Menyimpulkan bahwa ada hubungan antara pemakaian alat kontrasepsi dengan Pendidikan.

4. Hubungan antara pekerjaan dengan pemanfaatan pelayanan alat kontrasepsi $\mathrm{KB}$

Pekerjaan merupakan kegiatan yang dilakukan oleh seseorang untuk memperoleh penghasilan dalam memenuhi kebutuhan hidupnya.Ibu yang bekerja dimaksudkan untuk membantu menghasilkan pendapatan keluarga sedangkan ibu yang tidak bekerja yakni yang tidak dapat menghasilkan uang dan menjadi ibu rumah tangga.Pada keadaan hamil, ibu terutama dengan keadaan ekonomi keluarga di tingkat subsisten tetap melakukan pekerjaan fisik, seperti membantu suami bekerja di sawah atau berdagang.

Hasil penelitian ini menunjukkan tidak ada hubungan antara pekerjaan dengan pemanfaatan pelayanan alat kontrasepsi pada pasangan usia subur dikarenakan pekerjaan responden lebih banyak sebagai ibu rumah tangga jadi pekerjaan tidak mempengaruhi untuk melakukan penggunaaan alat kontrasepsi.

Hasil penelitian ini sejalan dengan penelitian yang dilakukan oleh Pardede (2012) menunjukkan bahwa tidak terdapat pengaruh pekerjaan terhadap pemanfaatan pelayanan program KB $(p>0,005)$.

5. Hubungan antara pemberian informasi dengan pemanfataat pelayanan alat kontrasepsi KB

Pemberian informasi mereupakan Pemberian informasi dalam program $\mathrm{KB}$ di kenal dengan istilah KIE (Komunikasi ,informasi dan edukasi) yaitu suatu proses komunikasi dengan penyebaran informasi guna mempercepat tercapanyai perubahan perilaku dari masyarakat. Dengan adanya pemberian informasi $\mathrm{KB}$ oleh petugas diharapakan dapat memberikan perubahan perilaku dan tindakan sehingga secara sadar menjadi akseptor KB.

Hasil penelitian menunnjukkan bahwa pemberian informasi ada hubungan yang bermakna antara pemanfaatan pelayanan alat kontrasepsi KB.Pasangan usia subur yang pernah mendapat pemberian informasidan tidak memanfaatkan pelayanan alat kontrasepsi disebabkankarena peserta KB menggunakan alat konntrasepsi yang dikatakan keluarganya atau temantemannya sehingga penjelasan mengenai jenis alat kontrasepsi yang sesuai dengan umur peserta KB tidak sesuai yang diinginkan serta penjelasan mengenai efek samping yang mungkin saja ditimbulkan oleh alat kontrasepsi yang akan digunakan terkadang diabaikan. Informasi yang didapat dari.

petugas KB sama sekali tidak mempengaruhi keputusannya menggunakan alat kontrasepsi kecuali alat kontrasepsi yang telah 
dipilih menimbulkan efek samping yang dirasakan oleh peserta KB dan meminta untuk mengganti alat kontrasepsi yang sesaui dengan umur dan kesehatan.Sehingga informasi yang didapat dari petugas kesehatan, media sosial, media elektronik, buku, iklan atau koran dan sebagainyasebagai sumber informasinya yang didapatkan. PetugasKB berperan dalam memberikan informasi, penyuluhan dan penjelasan tentang alat kontrasepsi bagi akseptor yang masih ragu-ragu dalam penggunaan alat kontrasepsi dan memutuskan untuk menggunakan alat kontrasepsi tersebut atas saran dari petugas KB. Perlunya informasi bagi masyarakat dikarenakan membantu kesuksesan program KB. Penelitian ini sejalan dengan penelitian yang dilakukan oleh Hasnawati pada akseptor KB di Kabupaten Barru tahun 2007 yang mengatakan ada hubungan antara penerimaan informasi dengan pemilihan alat kontrasepsi.

Disamping itu masih banyak ibu-ibu yang menentukan metode yang dipilih hanya berdasarkan informasi dari akseptor lain berdasarkan pengalaman masing-masing. Sebagian petugas kesehatan kurang melakukan konseling dan pemberian informasi yang menyebabkan kurangnya pengetahuan dalam memilih jenis kontrasepsi.

6. Hubungan anatra dukungan suami dengan pemanfaatan pelayanan alat kontrasepsi $\mathrm{KB}$.

Dukungan suami, seperti mengetahui bahwa istrinya ber-KB, setuju, dan tahu jenis alat kontrasepsi yang digunakan istrinya, mengawasi efek samping dari konntrasepsi istrinya, serta mengantar istrinya ke tempat pelayanan kesehatan untuk ber-KB merupakan hal yang sangat penting, terkait dengan ketidakteraturan istrinya dalam menggunakan alat kontrasepsi.Dukungan suami dapat menjadi motivasi tersendiri bagi istri untuk taat dan patuh terhadap aturan penggunaan alat kontrasepsi yang sedang digunakan.Dengan adanya kesepakatan antara keduanya mengenai kontrasepsi yang dipakai oleh suami/istri menyebabkan pemakaian alat kontrasepsi dapat berlangsung secara terus menerus.

Menurut Kusmiati (2000), peran suamidalam rumah tangga adalah sebagai kepala rumah tangga yang bertugas memimpin, melindungi dan bertanggungjawab terhadap keluarganya. Hubungan laki-laki dan perempuan bukan dilandasi konflik dikotomis, bukan pula struktural fungsional, tetapi lebih dilandasi kebtuhan kebersamaan guna membangun kemitraan yang harmonis.Begitu pula dalam pengambilan keputusan memilih alat kontrasepsi, kesepakatan antara suami dan istri sangat diperlukan untuk menjaga keharmonisan keluarga.
Hasil penelitian ini menunjukkan bahwaada hubungan antara dukungan suami dengan pemanfaatan pelayanan alat kontrasepsi KB.Hal ini berarti bahwa responden yang mengatakan bahwa suami mereka tidak mengantar dan tidak mengawasi efek samping penggunaan alat kontrasepsi mereka.Dukungan suami sangat mempengaruhi istri untuk menggunkan kontrasepsi.Apabila keinginan pasangan atau individu sangan kuat untuk mencegah kehamilan, maka hal ini secara langsung berpengaruh terhadap seberapa teratur mereka menggunkan metode kontrasepsi yang digunakan.

Beberapa bentuk dukungan suami yang diberikan kepada istrinya yang menggunakan kontrasepsi dengan memberikan saran dalam memilih kontrasepsi yang digunakan, mengantar istri ketempat pelayanan kontrasepsi, dan mengingatkan istri untuk melakuakn kunjungan ulang.Jika jarak tempat pelayanan kesehatan jauh, mereka biasanya lebih memilih menggunakan ojek atau berangkat dengan tetangga rumahnya.Mengenai efek samping dari penggunaan alat kontrasepsi, suami responden harus memang melakukan engawasan,inikarena suami responden banyak yang tidak mengetahui bahwa efek samping yang akan muncul saat istri mereka menggunakan salah satu alat kontrasepsi.

Adapun suami yang tidak mendukung pasangannya seperti tidak mengantar istrinya ketempat pelayanan atau pemahaman suami tentang dukungan kepada istri dalam pemilihan kontrasepsi terbatas pada mengizinkan dan hanya mengetahui saja tanpa ada tindakan yang lebih lanjut. Istri biasanya juga tidak membicarakan kepada pasangannya mengenai alat kontrasepsi yang akan digunakan atau telah dipilihnya dengan alasan bahwa suami telah memberikan kebebasan dalam menentukan jenis alat kontasepsi yang akan digunakan.

Responden dengan suami yang mendukung dan memanfaatkan pelayanan alat kontrasepsi KB sebesar 59.3\%. Sedangkan responden dengan suami yang tidak mendukung dan memanfaatkan pelayanan alat kontrasepsi $\mathrm{KB}$ sebesar $81.6 \%$. Hasil penelitian ini menunjukkan bahwa dukungan suami ada berhubungan dengan pemanfaatan pelayanan alat kontrasepsi $\mathrm{KB}$ pada pasangan usia subur dengan nilai $\mathrm{p}<0,05$ yaitu 0,038 .

Hasil penelitian Aryanti (2014) ini menunjukkan bahwa ada hubungan antara dukungan suami dengan penggunaan kontrasepsi pada wanita kawin usia dini di Kecamatan Aikmel Kabupaten Lombok Timur.

Mengenai kurangnya pengewasa suami terhadap efek samping dari penggunaakan alat kontrasepsi yang digunakan oleh pasangan 
mereka dan perlu kiranya edukasi kepada suami agar lebih memperhatikan agar kesehatan pasangan mereka saat menggunakan salah satu alat kontrasepsi.Biar bagaimanapun setiap tindakan medis atau pemilihan penggunaan layanan kesehatan harus ada kesepakatan antara suami dan istri.

\section{PENUTUP}

\section{A. Kesimpulan}

Berdasarkan hasil penelitian tentang faktor yang berhubungan dengan pemanfaatan pelayanan Alat Kontrasepsi KB pada PUS di Puskesmas TamalanreaKota Makassar, maka disimpulkan sebagai berikut:

1. Ada hubungan antara umur dengan pemanfaatan pelayanan alat kontrasepsi KB pada PUS di Puskesmas Tamalanrea Kota Makassar $(p=0,009)$

2. Tidak ada hubungan antara pengetahuan dengan pemanfaatan pelayanan alat kontrasepsi KB pada PUS di Puskesmas Tamalanrea Kota Makassar $(\mathrm{p}=0,448)$

3. Ada hubungan antara pendidikan dengan pemanfaatan pelayanan alat kontrasepsi KB pada PUS di Puskesmas Tamalanrea Kota Makassar $(\mathrm{p}=0,046)$

4. Tidak ada hubungan antara pekerjaan dengan pemanfaatan pelayanan alat kontrasepsi KB pada PUS di Puskesmas Tamalanrea Kota Makassar $(p=0,291)$

5. Ada hubungan antara pemberian informasi dengan pemanfaatan pelayanan alat kontrasepsi KB pada PUS di Puskesmas Tamalanrea Kota Makassar $(\mathrm{p}=0,036)$

6. Ada hubungan antara dukungan suami dengan pemanfaatan pelayanan alat kontrasepsi KB pada PUS di Puskesmas Tamalanrea Kota Makassar $(\mathrm{p}=0,038)$.

\section{B. Saran}

1. Petugas kesehatan sebaiknya memberikan informasi tentang jenis alat kontrasepsi $\mathrm{KB}$ seperti pil, suntik, kondom, IUD, implant, MOW/MOP pada pemanfaatan pelayanan alat kontrasepsi KB pada PUS untuk meningkatkan pengetahuan tentang penggunaan alat kontrasepsi yang lebih efektif bagi kesehatan ibu dan anak.

2. Perlu memperkenalkan tentang metode kontrasepsi yaitu metode sederhana, metode modern/efektif agar lebih diperluas jangkauannya dan menyebarluaskan kepada masyarakat atau pasangan usia subur dalam hal jenis-jenis kontrasepsi tentang keuntungan dan kerugiannya (efek samping) dari setiap jenis kontrasepsi.

3. Perlu adanya pemberian informasi kepada para suami tentang alat kontrasepsi agar mereka memahami tentang tujuan dan efek samping dari alat kontrasepsi. Sehingga suami lebih memperhatikan kesehatan istrinya yang mungkin di derita istri dari penggunaan alat kontrasepsi.

\section{DAFTAR PUSTAKA}

Ajeng, 2009. Prevalensi Penggunaan Kontrasepsi Pada Pasangan Usia Subur di Puskesmas Ciputat Tahun 2009.

http://(perpus.fkik.uinjkt.ac.id). Diakses pada tanggal 1juni 2014.

Awalina, Nur R. 2006. Hubungan faktor sosialDemografi dan Faktor Pelayanan Keluarga Berencana Terhadap Pemakaian Kontrasepsi Jangka Panjang pada Pasangan Usia Subur Di Provensi Nusa Tenggara Timur. Di Akses pada tanggal 8 September 2016

Aryanti, 2014. Faktor-faktor yang Berhubungan Dengan Penggunaan Kontrasepsi Pada Wanita Kawin Usia Dini Di Kecamatan Aikmel Kabupaten Lombok Timur. Diakses Pada Tanggal 4 juni 2015.

BKKBN. 1992. Undang-undang no 10 Tahun 1992 Tentang Perkembangan Kependudukan dan Pembangunan Keluarga Sejahtara. Jakarta.

Dinkes Kota Makassar, 2013.Profil Kesehatan Kota Makassar 2014.

http://(dinkeskotamakassar). Diakses pada tangggal 6 mei 2015

Dinkes, 2013. Sulsel Prov.go.id. Diakses Pada Tanggal 6 Mei 2015

Dwiyanto, Keluarga Berencana Kesehatan Reproduksi Gender dan Pembangunan Kependudukan di Indonesia. Bandung

Rineka Cipta, 2003 Djokowijono. Manajemen Kesehatan Ibu Dan Anak( Pendekatan Dan Strategi Pendekatan Komunitas. Duta Prima Airlangga, Surabaya

Faridah Ida. Faktor Yang Merupakan Determinan Kepatuhan Akseptor Kontrol Ulang KB Suntik 3 Bulan di Kecamatan Mulyorejo Surabaya tahun 2014, Tesis Universitas Erlangga. Di akases tanggal 4 Juni 2015

Grestasari, Erdika. Hubungan Antara Tingkat Pendidikan, Pengetahuan, Dan Usia Ibu PUS Dengan Pemilihan Jenis Kontrasepsi Di Desa Jetak Kecamatan Sidoharjo Kabupaten Sragen. 
Hasnawati.2009. Faktor-faktor Yang Berhubungan Dengan Pemilihan Metode Kontrasepsi Pil Pada Akseptor KB Baru Di Kecamatan Soppeng Riaja Kabupaten Barru Tahun 2007. Skripsi Fkm Unhas.

Ita Handayani, Annisa Andriyani. Karakteristik Ibu Dengan Paritasdari 3 di Wilayah Kerja Puskesmas Gambirsari Surakarta. https://(www.google.co.id). Diakses pada tanggal 1 juni 2015.

Kemenkes RI, 2010. Profil Kesehatan Indonesia. Jakarta

Muhajirah, 2004. Analis Penggunaan Alat Kontasepsi KB dan Perkembangan Fertilitas di Kec.Panakukkang Kota Makassar. Tesis Pascasarjana Unhas.

Manuaba, Ida Bagus Gede. Ilmu Kebidanan Penyakitkan dan Keluarga Berencana untuk Pendidikan Bidan, Jakarta. EGC. 1998. http://(repository.usu.ac.id). Diakses pada tanggal 1 juni 2014

Notoatmodjo, soekidjo. 2002. Metode Penelitian

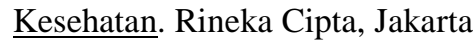

Nazilah.,2012. Kontribusi Otonomi Perempuan dalam Rumah Tangga Terhadap Pemakaian Kontrasepsi Di Nusa Tenggara Timur. Di Akses pada tanggal 15 Desember 2016.

Puskesmas Tamalanrea Kota Makassar, 2013. Profil Kesehatan Puskesmas Tamalanrea.

Pardede, Nasution, 2012. Determinan Pemanfatan Pelayanan Program KB pada Pasangan Usia Subur (PUS) di Kelurahan Kecamatan Babura Medan Sunggal tahun 2012. http://(jurnal.usu.ac.id). Diakses pada tanggal 11 Agustus 2014

Rifai, 2013. Faktor-faktor yang Berhubungan dengan Penggunaan Alat Kontrasepsi pada Pasangan Usia Subur Di Wilayah Puskesmas Buhu Kabupaten Gorontalo. DiAkses pada tanggal 1 Desember 2014

Widyastuti, Anik Hutari, 2011. Faktor-faktor yang mempengaruhi pemilihan Kontrasepsi Suntik depo Medroksi 